\title{
HOW GOOD IS TAMA RYEGRASS?
}

\author{
W. R. ScotT \\ Department of Plant Science, Lincoln College \\ K. R. Brown \\ Grasslands Division, DSIR, P.B., Christchurch
}

\section{INTRODUCTION}

'Grasslands TAMA' Westerwolds ryegrass (Lolium multiflorum Lam.) is a tetraploid cultivar of an extreme annual form of Italian ryegrass, bred in New Zealand and released into certification in 1967 (Barclay and Vartha, 1966). Tama has been used mainly as a greenfeed crop to provide high quality production feed for use in late pregnancy and early lactation and should not be confused with winter maintenance feed crops such as swedes and turnips.

Seed sales of Tama on the domestic market have declined in recent years, no doubt caused in part by the high cost of seed and by poor performance from sowings in dry autumns. To ensure reliability of Tama feed supply in late winter-early spring, correct husbandry in the previous months is required. It is the purpose of this paper to review this husbandry in the light of recent research findings.

\section{SOWING AND SEEDLING ESTABLISHMENT}

If there is a catch phrase which has meaning for successful Tama growing, it must be "Get Tama moving early."

Unsatisfactory late winter-early spring production can usually be traced back to lack of plant development in the first 6 to 7 weeks following sowing. Late sowing at the end of April through May is a major cause of delayed growth. The most appropriate time for sowing Tama in the South Island has been shown to be late summer-early autumn, i.e., February-March (Harris et al., 1973), nthough later sowings may be satisfactory in the North Island.

In regions where soil moisture is adequate for germination, seedling emergence, and seedling survival and growth, FebruaryMarch sowings pose few problems. However, in dryland regions such as the Canterbury Plains, early sowing, and indeed the use of Tama, can be ruled out if simple precautions are not taken. 
TAMA RYEGRASS

TABLE 1: PERFORMANCE OF TAMA FROM SOWING TO MID-SPRING

\begin{tabular}{|c|c|c|c|}
\hline & 1977 & 1977 & 1978 \\
\hline Summer fallow & Yes & No & Yes \\
\hline Soil moisture $(\%)$ & 22 & 11 & 13 \\
\hline Days to seedling emergence & 7 & 49 & 21 \\
\hline Yield (kg DM/ha) March-May & 1700 & Nil & 700 \\
\hline May-September & 3300 & 1800 & 2800 \\
\hline
\end{tabular}

These include the use of irrigation or, where this is not available, the use of a summer fallow (Table 1). At Grasslands Division's research unit at Kirwee in central Canterbury, the summer fallow consists of ploughing and rolling in mid-December, leaving alone until early March, and then Dutch harrowing and sowing at $20 \mathrm{~kg}$ seed/ha with $150 \mathrm{~kg}$ superphosphate/ha.

\section{AUTUMN DEFOLIATION}

The desirability of autumn grazing seems to depend primarily on the amount of early growth. In crops capable of producing about $2000 \mathrm{~kg} \mathrm{DM} / \mathrm{ha}$ by late August, autumn grazing may increase yield (Barclay and Vartha, 1966; Harris et al., 1973; Vartha and Rae, 1973). However, results from current work at Kirwee indicate that in years when autumn growth of Tama is slow, grazing at this time does not improve winter-early spring performance (Table 2), although it may have a positive effect later in the season, a result similar to that obtained by Vartha and Rae (1973). Further work remains to be done for seasons when autumn growth is good.

TABLE 2: AUTUMN GRAZING FOR EARLY SPRING PRODUCTION

\begin{tabular}{lccc}
\hline $\begin{array}{l}\text { Autumn } \\
\text { Grazing }\end{array}$ & At $7 / 8 / 78$ & $\begin{array}{c}\text { Yield }(\mathrm{kg} \text { DM/ha }) \\
7 / 8-29 / 9 / 78\end{array}$ & $29 / 9-1 / 11 / 78$ \\
\hline Yes & 1100 & 1850 & 3390 \\
No & 1750 & 1720 & 3260 \\
\hline
\end{tabular}

\section{INTENSITY OF SPRING GRAZING}

Many farmers begin using Tama about 4 to 5 weeks before lambing. At this time Tama is break fed and nearly always hard grazed. In August-September 1978, at Kirwee, increasing intensity of the first grazing in spring had a small positive effect on produc- 
TABLE 3: INTENSITY OF SPRING GRAZING

\begin{tabular}{ccc}
\hline & \multicolumn{2}{c}{ Yield $(\mathrm{kg}$ DM/ha) } \\
Intensify & $7 / 8-29 / 9 / 78$ & $29 / 9-1 / 11 / 78$ \\
\hline Hard & 1880 & 1700 \\
Lax & 3480 & 3160 \\
\hline
\end{tabular}

tion over the two subsequent recovery periods (Table 3). However, in many instances grazing frequency is much shorter than that shown in Table 3, and it has been shown that, when compared with infrequent hard grazing, frequent hard grazing is detrimental to Tama production (Harris et al., 1973).

\section{NITROGEN AND TAMA PRODUCTION}

The effect of $\mathrm{N}$ on Tama yield is variable: applications at sowing, in late autumn, and in spring have varied from no effect (Vartha and Allison, 1973) to marked responses (Vartha and Rae, 1973; Harris et al., 1973). Many farmers, particularly in Canterbury, have used a mid-winter (June) application to boost early spring production. Vartha and Rae (1973) have shown positive responses to nitrogen applied at this time, but have also reported no response in an extremely wet winter. At Kirwee in 1978, a mid-winter (June) application of $\mathrm{N}$ was compared with a late winter-early spring (2nd week of August) application, the latter being applied immediately after the first late winter-early spring grazing. The winter was wet and by early August there was no response to mid-winter $\mathrm{N}$, in contrast to the $50 \%$ yield increase over the 8 weeks following the August $\mathrm{N}$ application (Table 4).

TABLE 4: NITROGEN FOR EARLY SPRING PRODUCTION

\begin{tabular}{lccc}
\hline Time of $N$ & Yield $(\mathrm{kg} \mathrm{DM/ha})$ & \\
Application & A/8/78 & $7 / 8-29 / 9 / 78$ & 29/9-1/11/78 \\
\hline Mid-June & 1390 & 1430 & 3210 \\
Early August & 1460 & 2150 & 3430 \\
\hline
\end{tabular}

\section{SEED SIZE}

At both Palmerston North and Lincoln, Tama produced yields between 7000 and $9000 \mathrm{~kg} \mathrm{DM} /$ ha by late August during the years preceding its release into certification (Barclay and Vartha, 1966). Subsequent yields have been considerably less, even in years with reasonable rainfall (Harris and Johnston, 1969; Crouchley and Bircham, 1971; Vartha and Rae, 1973; Vartha and 